\title{
Strengthening Agricultural Investment Through Sustainable Islamic Banking
}

\author{
Purbawati Setyaningsih $^{1 *}$, Acep R. Jayaprawira ${ }^{2}$ \\ ${ }^{1}$ Perbanas Banking Finance and Informatics Asia Institute (IKPIA), Bekasi 17114, Indonesia \\ ${ }^{2}$ Trisakti University (Usakti), DKI Jakarta 11440, Indonesia
}

\begin{abstract}
A B S T R A C T
This study analyzes how agricultural investments may strengthen the Islamic banking industry that is sustainable in the short and long term. Qualitative data sources are secondary data from BPS, Baznas, ACT Global Waqf and research on BWI in the form of secondary data from March 2007 to December 2018. Data were analyzed using the Error Correction Model (ECM) Methodology. Ziswaf have a significnt effect on GDP both of the long term and the short term, with the ECT coefficient was - 1.81E-07 meaning that there are increasing GDP will be adjusted within one (1) year with the residual speed of the balance value of - 181 percent. In the long term, the GDP have influented simultaneously by all independent variables with affected positively by Exports-Agi, PMDN and Ziswaf significantly; and it have influenced negatively by Export significantly at the R-square level of 0.98 meaning that the variables are tested to provide almost all the information needed to predict the GDP. Export-Agi was the most influence with a value of coefficient variable 44.875570 . While in the short term, GDP was significantly influenced by Ziswaf on R-square 0.26 which means that there have 74 per cent of other variables outside the model that affect GDP.
\end{abstract}

The selection of competitive plants in the zakat distribution program and the use of idle waqaf land is very important to be considered by institutions / individuals who are interested in PMDN investment in the agricultural sector and ziswaf management institutions. Every land and sea have the blessing and the competitive power of its own and its utilization as well as possible considering the state of the local community as a major source of labor, without neglecting the environment as part of sustainable development goals. A smart-smallmicrofinanc can be synergized with ziswaf as a step to strengthen the technical and managerial mustahik. Cash waqf can also be used as an instrument for the development of further capital. Economic growth is accompanied by sustainability is the best choice, the chance

\section{ART ICLE INFO}

\section{Article History:}

Received : 22-02-2020

Revised : :12-06-2020

Accepted : 17-06-2020

Published : 30-06-2020

Keywords:

Islamic Financing

Sustainable Islamic Banking

Agricultural Investment 
alignment of a sustainable Islamic financial investment can be expanded globally in scope and impact. Islamic financial transactions can be retained should provide investment categories permitted by religion (halal) and did well to supply logistics either through A-PLS or sukuk using the financing agreements like salam, muzara'ah, and mugharasah; irrigation infrastructure for areas prone to lack of water with Musaqa or Istishna financing. Careful handling prior to harvest, post-harvest handling of agricultural products and halal food processing industry is part of the growing Islamic Bankings sustainable advantage.
*Corresponding Author E-mail: purbawati.s@perbanas.id

\section{INTRODUCTION}

\section{The Background}

The financial sector is a means that bridges the interests of those who have excess funds (deposit funds or creditors) and those who need funds (borrowers of funds or debtors) with banks as intermediaries. The Islamic finance sector is booming, from a market of just $\$ 200$ bn in 2003, the sector is expected to grow to over $\$ 4$ trn in assets by 2030. Islamic contracts fall into three broad categories: trade-oriented transactions (debt-like instruments), equity (profit-and-losssharing) and support contracts. Each of these categories creates an opportunity for new sustainability oriented products. The characteristic of products have four main features: 1) Asset backed, 2) Ethical, 3) Share risks equitably and 4) Subject to good governance (Usher and Ndiaye, 2020). The sustainability and viability of Islamic finance come from fundamental requirements set by principles of the Sharia Law. Islamic transactions should strictly adhere to the permissible (halal) and abstain from the prohibited (haram). As will be reviewed below, these requirements are implied by divine rules that include prohibition of riba (interest), gharar (ambiguity), maisir (gambling) and commodities such as intoxicants and pork (Myers and Hassazadeh, 2013).

The financial sector has a very important function in international trade, as well as providing convenience services for transactions between countries. In the macroeconomic context the financial sector has a role as a means of transmitting monetary policy so that the shock that occurs in the financial sector can affect the effectiveness of monetary policy. The financial sector plays an important role in economic growth and development (Miller, 1998). The employment effect appears to be correlated with the level of sustainability of agricultural practices, with an estimated 30 percent increase in employment for sustainable agriculture, compared to unsustainable practices. The International Institute for Sustainable Development (2014) states that the welfare of the country is so important, so that agricultural trade has always been, and continues, a major issue of controversy multilateral trade negotiations. Many developing countries have the advantage in agricultural production compared with their developed country trading partners, but are not able to exploit the growth potential of this machine.

In many developing countries (even in countries where the agricultural sector is not a large component of national GDP) agriculture is an important work base for most of the population. The employment effect appears to be correlated with the level of sustainability of agricultural practices, with an estimated 30 percent increase in employment for sustainable agriculture, compared to unsustainable practices. Basically, economic growth measures a country's ability to expand output levels faster than population 
growth rates. Increased economic growth rate is affected by such an increase in exports and increased investment. The concept of green growth is a concept that is based on sustainable and environmentally friendly economic development, facing the problem of global warming. In an open economic system, exports will generate revenues that would be used to finance imports, particularly imports of capital goods and raw materials required in the production process that will create added value.

Investment or capital investment is also a component of value added to national building, which is the purchase of capital goods and production equipment to improve the ability to produce goods needed in the economy (Sutawijaya, 2010). Trade must be used as a positive catalyst for economic, social and environmental change, rather than encouraging environmental degradation. Green-economy presents a model for reversing this trend, with changing economic policies and incentives by supporting social growth, justice and prosperity through conservation, using nature by preserving resources and alerting pollution control. Economic growth have characterized by the growth of output per capita and rised living standards, the value of economic growth have measured by the level of growth in gross domestic product (GDP) in constant prices. The main driver of economic growth (an environmental point) at the moment is expancing and liberalizating global trade that does not harm the natural environment. While trade growth in 2050 have expected to be driven by tripled of global population and kuartered of the increased current GDP.

The agricultural sector was influenting economic growth on the second most influential after the processing industry and still above the trade and construction sector. More than half of the GDP of the manufacturing industry have agriculturebased. In a holistic agricultural sector from upstream (or on farm) to downstream (or down stream industries) on a value chain, it was contribution to GDP in aggregate reaches around
55 percent. If the types and value chains of agricultural commodities which numerous and numerous in Indonesia, was using developed technology and have supported by modern logistics systems, so Indonesia's GDP will increase potentially and also the welfare of farmers and other rural economic actors will increase too. The agricultural sector also the biggest absorber of labor, which was about 35 percent of the total workforce (Hadad, 2016). According to BPS (2017) the total population over the age of 15 years working in Agriculture, Plantation, Forestry, Hunting and Fisheries was 31.9 percent.

The function of agriculture in development is to improve the agricultural sector, increase economic growth, reduce poverty, increase income, provide food security, and provide environmental services. However, the government and donors have stopped this agricultural function, leaving behind agricultural growth which has now declined. Currently 75 percent of world poverty occurs in rural areas, sectoral income disparities have been destroyed, food insecurity has returned, and widespread environmental degradation, sustainability sustainable. Mobilizing these functions request the transfer of political economy to overcome the bias of anti agricultural policies, manage governance for agriculture, and adjust the priority with the requirements of the State (Sukirno, 2006).

Nigeria, the western part of Africa has large agricultural work, in addition to storing various minerals including petroleum, natural gas, lead, iron ore, and coal; also has a growing fast foreign trade, a lmost 95 percent of foreign exchange is the result of oil exports. The state of Kano is an important agricultural, forestry and fishery place in Nigeria with population density and productivity. About 70 percent of the population works in agriculture, that's includes cocoa, palm oil, cotton and rubber farming. Agricultural products are the main export after crude oil; many cotton commodities are planted in the north which have sandy soil and temperate; coconut plantations are mostly cultivated in the south and produce coconut oil to make soap, cooking oil and 
lubricants. In Kano, Nigeria state agricultural financing available through the conventional banking system is less desirable due to high interest rates, and the majority of Muslim farmers in the country are very reluctant and aware of disobedience to religion. Then there was a decline in agricultural output. They was proposing an alternative agricultural activities that will benefit through one Islamic financial product called salam financing (Mohammed, Ogunbado \& Bashir, 2016).

Formal financial institutions that exist today tend to prioritize non-agricultural services that have high returns but the risk is low. Observations such as maturity, the potential for, and constraints in developing social funds in Indonesia in his role in the agricultural sector needed to boost national economic development, although development was not fully supported by adequate capital. Islamic Bankings (IBs) in Indonesia is not dominating the economy (Sunarmo, 2018). Financial literacy on community's understanding of banking as a financial intermediary institution just only 21,80 percent that was lower compared to Philippines (27 percent), Malaysia (66 percent), Thailand (73 percent) and Singapore with the highest level of understanding of the banking sector i.e. 98 percent. The low level of banking literacy indicates that many people do not know condition of Ibs. In the long run, does not show equilibrium means IBs in a developing condition. There for the collaboration between goverment, Indonesia FSA and BI, banking and the community is needed to increase the growth its in the future. IBs operates on monopolistic market and perfect competitions, means Ibs has not been consistent in developing its products so requires $\mathrm{t}$ he development of exellent products with spesific characteristics and market share.

For investment funding, that the social sector of Islamic finance has the potential to push further the commercial sector and reciprocally shake in terms of social welfare benefits for the community (Ismal, et.al., 2015). This reciprocal relationship can be a potential catalyst for sustainable economic development and efforts to deepen
Islamic finance. For this reason, the project-based sukuk in the spirit of developing the real sector through the social sector can be innovated. Specifically, sukuk is related to waqf with waqf assets as part of the basic assets arranged in a combination of commercial (tijari) and noncommercial (tabbaru) schemes. Mulyawan (2017) describes the role of Islamic Social Finance scheme (ISF) in accelerating the growth of the national economy and can take a high growth rate and consistently to avoid the middle income trap. Factors that affect the economic growth were the industrial structure, disparity, efficiency, human resources, investment and macro-policy.

Contributions ISF to accelerate growth in National Economy 2016-2025, a phase strengthening the economic structure, is predicted with an average growth target of 6 percent per year and 6.7 percent at the end. To optimizing Development of ISF to the front should be supported by information systems, standards and international accounting standards influence on the achievement of a high governance standards with the development of 1) Monitoring efficient, 2) An effective regulatory framework and compatible with other sectors, 3) The quality of human resources, 4) An effective educational program.

\section{Research purposes}

The purpose of this research are:

1. To determine the effects of domestic capital investment, Islamic social funds and international trade of agricultural sector to sustainable economic growth.

2. To explore the potential of islamic banking and the sukuk structure to assist agricultural development towards food security, increase state income and equitable sustainable economic growth.

\section{LITERATURE REVIEW}

Effect Agriculture to Food Security and Sustainable Economic Growth

In a hadith, the Prophet sallallaahu 'alaihi wa sallam said, 'The Muslims unit (in ownership) on three things: grasses (which grow in no man's land), water (rain water, springs, and river water), 
and firewood (collected by humans from trees).' (Narrated by Abu Daud no. 3477 and Ahmad 5: 346. Shaykh Syu'aib Al Arnauth and Al Hafizh Abu Thohir said that the hadith authentic. See the explanation of Al Baydhowi quoted by Al Munawi in Faidhul Qodir 6: 271) (rumaysho.com/3353). 'Grasses' can be interpreted as plants food, both for livestock and humans, while 'fire' can now be interpreted as energy. All three must not be owned by individuals. Ibnul Qayyim rahimahullah said, 'The person who put water in his container (packaging) did not include in the hadith. The water that we had put in our containers like goods that are originally public property but we had moved into our power and want us to sell, such as firewood taken from the forest, a bunch of grass we collect, and salt we take from the sea'.

The hadith above can be understood also that food, water and energy we have is not ours absolute $100 \%$. Because the substance is the common property of mankind. This means that human association is due to the position of water, grassland and fire as public facilities needed jointly by a community or socienty. Therefore we need to be careful to use it so it does not use other people's rights by means of redundant and superfluous. Because the nexus of the universe or the network for the water-energy-food is interrelated to the survival of human life. This hadith is also in harmony with constitution UUD 1945 Article 33 paragraph 3 which was formulated by the founding scholars of this country that 'The Earth, water and natural resources contained therein are controlled by the State and used for the greatest prosperity of the people' (MUI-LPLHSDA, 2017).

The preparation of a framework for sustainable development, must bring further economic interests and environmental sustainability, provide a process of economic transformation, and expand access to society out of poverty and justice. This is a consideration that social and environmental problems that have not been included in economic calculations are important elements that need to be considered. Balance between the interests of profit does not mean giving legitimacy to lose attention and commitment to protect the environment and better social life (OJK, 2017). Existing formal financial institutions tend to prioritize non-agricultural services that have high returns but low risks. Related to the national economic development, social development fund for the agricultural sector in Indonesia needs to be examined because the sight of their development is often not fully supported by adequate capital, and the necessary exploration maturity, potential, and their barriers. Islamic scholars in the use of waqf marked as protecting resources and the supply of public goods for the benefit of the Muslims in general. In the tradition of Waqf has contributed significantly such as schools, hospitals and universities.

Agricultural business (in a broad sense) is related to the organism and its environmental ecosystem. In Indonesia, according to Law No. 32 of 2009 on the Protection and Environmental Management, sustainable development has a conscious and planned effort that integrates environmental, social and economic development strategies to ensure the integrity and safety of the environment, ability, well-being and quality of life for the current generation and the future in order to establish integrated ecosystem. This includes the planning, utilization, control, maintenance, monitoring and enforcement (Samad, 2016).

Small-scale farmers represent 90 percent of the rural poor and make up the majority of the world's starving population. FAO seeks to protect livelihoods from shocks, make food production systems more resilient and more able to absorb impacts, and recover from disturbing events; with Food and Nutrition Safety through the FAO Interdisciplinary Framework Program: Resilient Livelihoods. The program contains strategic directions to FAO member countries and partners for implementing disaster risk reduction measures in agriculture, forestry and fisheries at the local, national, regional and global levels. This Framework Program reflects the Hyogo Framework for Action and seeks to help member countries implement the five Priorities for Action for the agricultural sector. The Framework 
Program supports national government partners, the direct beneficiaries are small farmers in developing countries, including small scale farmers, fishermen, herders, foresters and urban poor-especially women-whose lives and livelihoods are threatened. It also responds to the latest recommendations made on disaster risk reduction by the Agriculture Committee, Program and Finance Committee, the World Food Security Committee and the Fisheries Committee.

Investment or capital investment is also an added value component for the national building, the purchase of capital goods and production equipment to improve the ability to produce the goods needed in the economy (Sutawijaya, 2010). Environmental sustainability within the framework of Islamic Economics goal is maslahah. Command to preserve the environment stated in Surah Al-Baqarah [2]: 60 which means: And (remember) when Moses prayed for water for his people; We said: 'Strike the rock with your staff'. Then gushed from it twelve springs. Indeed each tribe knew their drinking place (respectively). Eat and drink the sustenance (given) Allah, and do not roam the earth with mischief.'

Trade must be used as a positive catalyst for economic, social and environmental change, rather than encouraging environmental degradation. Green economy presents a model to reverse this trend, by changing economic policies and incentives by supporting social growth, justice and prosperity through conservation and use of nature by conserving resources and reminding pollution control. Green investment is an option to achieve sustainable green growth. Green investment has the potential to grow income and jobs that are more environmentally friendly, increase access to clean water and energy, increase the transfer of green goods and services, reduce carbon emissions and waste, and preserve biodiversity, ecosystems and forests.

Protecting the environment is associated with a doubling of crop enterprises (multicrops) to improve the quality of the climate, and waste management with production efficiency and management efficiency in the area of processing industry, as well as promoting the halal industry. Green industrial estates also makes it easy to estimate specific consumption, production and trade between countries, easily reduces the impact on biodiversity loss, and can provide useful insights for designing demand-side mitigation strategies and interventions. In trade, an increase in the price of environmental benefits provided by production companies, will be charged to consumers. It is a challenge for development economists.

Increasing agricultural productivity in appropriate and needed places, has the potential to reduce poverty in the future. A study has been carried out on a comparison of the characteristics of twenty-five developing countries that have had extraordinary success in reducing extreme poverty over the past twenty to twenty-five years, covering some of the poorest countries and some of the richest developing countries in the world, representing almost all geographical regions, these countries are also very different in their economic management and management systems, using indicators of their macroeconomic characteristics and especially, their agricultural economic characteristics. Retrieved effectiveness of poverty reduction through increased farm income growth than other sectors because: 1) The high incidence of poverty in rural and agricultural population as compared to other places, and 2) most of the poor people in rural areas and their livelihood largely depends on agriculture (Cervantes-Godoy \& Dewbre, 2010).

South Korea was the first country in the world to establish the concept of national policy since 2008 in an effort to increase the country's independence and reduce the impact of climate change. South Korea has now changed from a poor agrarian country into a developed industrial countries (Putra, 2014). Now, Indonesian's important agendas for food security are improving the competitiveness of agricultural commodities. According to BPS data for 2017, the Indonesian agriculture sector contributes to GDP at least 
percent. A total of seven types of commodities contributed to the agricultural sector. These commodities include Plantation (3.47 percent), Food Crops (3.22 percent), Fisheries (2.57 percent), Livestock (1.57 percent), Horticulture (1.44 percent), Forestry (0.67 percent), and Agriculture and Plantation Services (0.19 percent).

\section{Investment Agricultural Trade trough ISF, Islamic Banking and Sukuk}

Raumah wells in Medina was originally owned by Jews, who at the time of prolonged droughtstricken, the wells are no longer left only one clean water from the well. Muslims of Medina flock to queue up and buy water from those wells to meet the requirements, then the Rasulullaah salallahu 'alaihi wassalam respectfully said, ' $O$ my friend, anyone among you who donate their property to be able to free up the well and donate it to the people, it will memdapat His heaven Allah Ta'ala' (Narrated by Muslim). In practice, according to the management of waqfas-Sunnah wells belonging to Ustman bin Affan radialahu anhu still available now, actively used by the people of Madina and bordered by a fence and can be viewed from outside the fence. Results management can be felt by the poor and those who need it, as well as being a source of water in the surrounding land to irrigate palm plantations. Palm trees are managed for generations of caliph until the Saudi government under the Ministry of Agriculture.

Then, the Saudi government sells harvested date from the date palm plantation to the market. Half of the profits are distributing to orphans and the needy and the other half are keeping in the form of a bank account in the name of Ushman, held by the Ministry of Awqaf. The account money that continues to grow have used for the construction of hotels in the name of Ustman bin Affan Hotel. The hotel have managed by Sheraton, the one of the international standard hotels with 15 floors and 24 rooms on each floor, it is equipped with a large restaurant and shopping places as well as close to the Ustman bin Affan Mosque which is also still actively used (https://globalwakaf.com).

In Malaysia, idle land is land that can be used for cultivation but is now in a non-use status, or abandoned land, or vacant land for two years in a row according to the definition of the Department of Agriculture in Malaysia (DOA) used as potential inventory through endowments. Criteria for idle land are: 1) Rice land that has not been cultivated or used for grazing purposes for three years in a row; 2) Rice fields equipped with physical infrastructure for double planting but only single crops; 3) Rice land planted with plants other than rice; 4) Rubber and other tree plantations that are abandoned or not fully utilized as rarely tapped (Shafiai, Moi \& Ahmad, 2015).

Abdurrahman (2010) said that riba-free bank need do risk management through diversifications of sectors of economy; with the riba-free bank's credit policies committee devices an investment 'pie' that allocates the investment of its funds in each sectors; through applying the proper riba-free financing model that its grows from cost-plus (murabaha) to money management (mudaraba), joint venture (musharaka), leasing (ijara) and riba-free financing of future production ( $b a-i \quad u l$ salam/ishtisna); through diversification of client with spread a financing activity to the community without a financing into a small number af succesful businesspersons to result more clients on the investment side and bigger pool of reverals, and also distributed the probability of failure; through diversifications bt geografic location.

Figure 1 is Riba-free investment tools to developing the riba-free banking investment product. The investment pyramid displays the characteristics and nature of products that fit each layer. At the bottom of the pyramid, the advisor allocates a certain percentage of the customer's wealth in the form of cash equivalens,its include the demand deposit. The next layer of investment is a longerterm investment that can mature in three months to three years, such as automobile financing or a piece equipment. Riba-free based bond called sukuk.

Gini ratio, ZISWAF, total exports, and the Production Index Sharia Stock Index examined for their effects on GDP. In the long and short term 
models, the Gini Ratio, Ziswaf and Production Index have a significant positive effect on GDP, while total exports and the Sharia Stock Index both have no significant effect on GDP. If the value of the Gini Ratio, Ziswaf and Production Index decreases or slows down, the GDP also decreases. The Gini ratio can be increased through economic activities based on export-oriented agricultural resources through government policy support (Setyaningsih, Azis \& Hadiyati, 2019). The increase in exports can still be done to see the potential for idle waqf land in Indonesia. Unemployed agricultural land can become a burden because they have to pay taxes. Land as an economic resource if neglected, and in the end will not be able to generate income either for landowners or farmers. Unemployed agricultural land in Indonesia and for the development of exportoriented agriculture, has the potential to be activated using zakat and waqaf funds. Thus the structure of Islamic finance agricultural development through combination with other contracts, namely al-muzara'ah, al-musaqa and almugharasah could be an option.

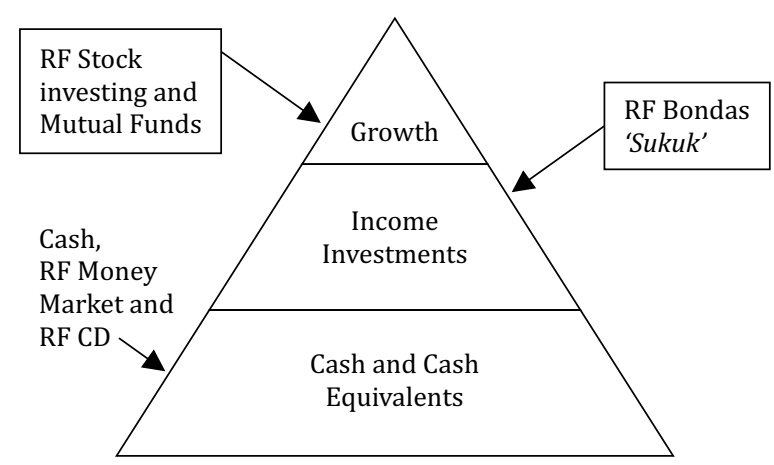

Figure 1. Riba-free Investment Tools

Source: Abdul-Rahman (2010)

Characteristic of Investment Sukuk are 1) Investment sukuk are certificates of equal value issued in the name of the owner or bearer in order to establish the claim of the certificate owner over the financial rights and obliglations represented by the certificate, 2) Investment sukuk represent a common share in the ownership of the assets made available for investment, whether these are non-monetary assets, usufruct, services or a mixture of all these plus intangible rights, debts and monetary assets. These sukuk do not represent a debt owed to the issuer by the certificate holder, 3) Investment sukuk are issued on the basis of Sharia'a- nominated contract in accordance with the rules of the rules Sharia'a that govern their issuance and trading, 4) The trading of investment sukuk is subject to the term that govern trading of the rights they represent, 5) The owners of these certificate share the return as stated in the subscription prospectus and bear the losses in proportion to the certificate owned (held) by them (AAOIFI, 2004).

Sukuk muzara'ah definition is found in the number $3 / 7$. This Sukuk defined as sukuk issued with the aim of mobilizing funds in the context of the financing of agricultural activities under the contract muzara'ah, so that sukuk holders are entitled to share of agricultural products in accordance with the agreement. In part 5/1/5/9, regulated Sharia provisions on the issuance of sukuk this type. In this case there are two types of sukuk namely sukuk issued by land owners or sukuk issued by land managers (workers). If the sukuk is issued by the land owner (landowner or land benefit owner), then the buyer of the sukuk acts as the manager of agricultural land based on the muzara'ah contract. The funds from the issuance of sukuk are funds for agricultural costs. Meanwhile, if the sukuk is issued by the land manager, the sukuk buyer acts as the owner of the land, where the funds from the sukuk issuance are used to buy agricultural land. So that the sukuk holders are entitled to a part of the land production according to the agreement (AAOIFI, 2004).

The definition of Sukuk Musaqah is in number $3 / 8$. This sukuk defined as a sukuk issued with the purpose of using funds from the issuance of sukuk to carry out irrigation activities for fruiting plants, paying operational costs and maintaining these plants based on the musaqah contract, so that the sukuk holders are entitled to a part of the harvest according to the agreement. In number 5/1/5/10 the sharia provisions regarding the issuance of these types of sukuk are regulated. In this case there are two types of sukuk musaqah that can be issued, namely sukuk issued by landowners who 
have plants on it or sukuk issued by land tenants. If the sukuk is issued by the land owner who has plants on it (the land owner or the land benefit owner), then the sukuk buyer acts as a land tenant based on the musaqah agreement. The funds from the issuance of sukuk are funds for irrigation and crop maintenance costs. Whereas if the sukuk is issued by the land tiller, the sukuk buyer acts as the land owner, where the funds from the sukuk issuance are used for crop irrigation. So that the sukuk holders are entitled to a part of the crop production according to the agreement.

Sukuk Mugharasah definition is found in the numbers 3/9. This Sukuk is defined as s ukuk issued under the contract mugharasah (agriculture), in the context of finance planting and maintenance fund, so that the investor is entitled to a land and crops.In number 5/1/5/11, Sharia provisions regarding the issuance of these types of sukuk are regulated. In this case there are two types of mugharasah sukuk that can be issued, namely sukuk issued by land owners or sukuk issued by land tenants. If the sukuk is issued by the land owner (landowner or land benefit owner), then the buyer of the sukuk acts as a planter based on the Mugharasah contract. The funds from the issuance of sukuk are funds for the cost of planting and maintaining plants. Whereas if the sukuk is issued by the land tiller, the sukuk buyers act as the owner of the land, where the funds from the issuance of the sukuk are used for the costs of planting crops. So that the sukuk holders are titled to part of the plants and land according to the agreement.

Other innovative financing is needed both community participation, cooperation between government and business entities and Blended Finance in the form of community participation so that the primary balance which is a combination of state revenue and expenditure minus debt interest payments, can be positive. Mulyawan (2017) stated that the ISF is a source of investment that is easily absorbed by the public. The ISF has the potential to connect and match untouched segments of society, because financing of the SME sector tends to have higher default rates and higher interest rates than the corporate and retail segments (Figure 2). ISF has the potential to do a link-and-match for the segment of society that is still untapped. The advantage of ISF is that they have available sources of funds to be absorbed so that they will not cause systemic risk.

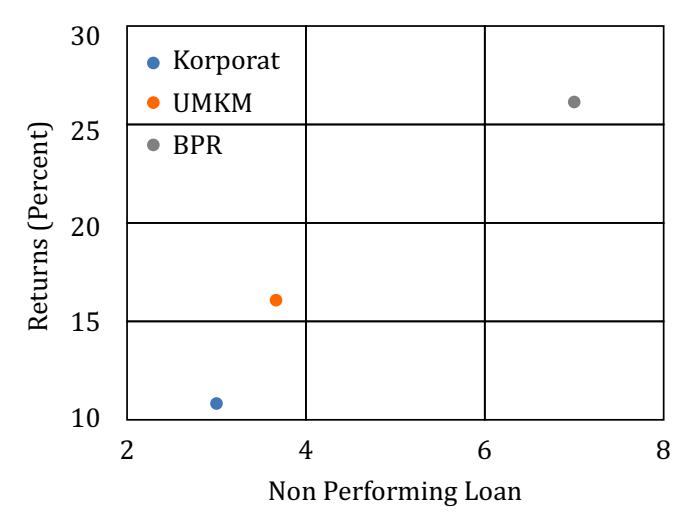

Figure 2. Non Performing Loan (NPL) of Corporate, UMKM and BPR

Source : Mulyawan (2017)

\section{RESEARCH METHODS}

This research consists of two parts, combines qualitative and quantitative analysis. One analysis is numerous variables that influence economic growth, with GDP benchmark using ECM methodology from secondary data and quantitative approaches. The second one is the effects of the research results to increased international trade through Islamic banking, using do cumentary methodology of qualitative approach. This research using Indonesian GDP data, the data Export-Industry-Agriculture (AGI EXPORT), Export-Total (EXPORT), Invest-InState (PMDN), and Zakat-Waqf (ZISWAF). Data sourced from the Central Statistics Agency (BPS), the Ministry of Trade, Bank Indonesia, the National Zakat Agency (Baznas) and from the Global Waqf-Fast Action Response from 20082017.

\section{Data processing ECM}

The stationarity test have done by testing the roots of unit or unit root test. If non-stationary data have had unit roots, otherwise stationary data did not have unit roots. This research have used Augmented Dickey Fuller (ADF) test model, that show the independent variables studied 
were stationary on the 2nd Different. After the independent variables and the dependent variable have fulfilled the condition of one (1), the next step is to make the estimated regression equation (2). Step estimated regression equation (2) is carried out after the independent variables and the dependent variable meets the condition (1). The cointegration test have done by tested its residu by the Augmented Engle-Granger. If the residual not stationary at the level, its have a longterm balance. This reseach stationary at the 2 nd Different (Table 1).

The equations for long-run is:

$\mathrm{Yt}=\alpha 0+\alpha 1 \mathrm{X} 1 \mathrm{t}+\alpha 2 \mathrm{X} 2 \mathrm{t}+\alpha 3 \mathrm{X} 7 \mathrm{t}+\alpha 4 \mathrm{X} 8 \mathrm{t}+$ et......(1)

GDPt $=\alpha 0+\alpha 1$ PMDNst $+\alpha 2$ EKSPOR AGIt +

$\alpha 3$ EKSPORIt $+\alpha 4$ ZISWAFmt + ECT.

From DF testing for residual unit root test (Table 1), it was found that the residual stationary at the degree level that is visible from the value of t-statistics are significant at the $5 \%$ critical value (Prob 0.0000). Data residues are stationary at level indicates that all cointegrated independent variables, so as to have along-term balance.

The equation of short term derivation estimates with stationerity at 2 nd Different are:

$\operatorname{LogGDPt}=\beta 0+\beta 1 D t+\beta 2 \operatorname{LogPMDNt}+$ $\beta 3 \operatorname{LogEKSPOR}$ AGIt $+\beta 4$ LogEKSPORt + $\beta 5$ DLogZISWAFt + ECT $(-1)$

$D(\log ($ GDPt -1$))=\beta 0+\beta 1 D t+\beta 2 D(\log ($ PMDNt -

$1))+\beta 3 D(\log ($ EXPORT AGIt-1) $)+\beta 4 D(\log$

$($ EXPORTt-1 $))+\beta 5 D(\log ($ ZISWAFt-1 $))+$ ECT

$(-1)$

ECT $(-1)=$ DlogPMDNt-1 + DlogEKSPOR AGIt-1 +
DlogEKSPORt-1 + DlogZISWAFt-1

Where:

LogGDPt : Economic growth in period $t$

LogPMDNt : Investment of Domestic Investment period $\mathrm{t}$

LogEXPORT-AGIt : Export Value of Agriculture and Manufacturing Industry period $\mathrm{t}$

LogEXPORTt: Export Value Total period $\mathrm{t}$

LogZISWAFt : Amount of Zakah and Endowments in period $t$

$\mathrm{D}(\log \mathrm{PDB}(\mathrm{t}-1))$ : Slowdown in Economic Growth $\mathrm{D}(\log P M D N I(t-1))$ : Inaction of Investment Domestic Investment

D(LogEXPORT AGIt-1) : Inaction of Agricultural Exports and $\mathrm{P}$ rocessing Industries

(LogEXPORT(t-1)) :Total Export Slowness

$\mathrm{D}(\operatorname{LogZISWAF}(\mathrm{t}-1))$ : Ziswaf Slowness

D :Change

$\mathrm{T} \quad$ :Period of time

ECT :Residual

ECT $(-1) \quad:$ Residual $\mathrm{t}-1$

$\alpha 0 \alpha 1 \alpha 2 \alpha 3 \alpha 4 \quad$ : Long-term Coeficient

$\beta 0 \beta 1 \beta 2 \beta 3 \beta 4 \quad$ :Short-term Coefficient

\section{Stages Analysis Result Data}

A second study using documentary methodology of qualitative analysis, especially in developing arguments in the development potential of Islamic banking, management effectiveness Awqaf, waqf land use and empowerment of the State Owned Enterprises, as well as the relevant legal framework.

\section{ANALYSIS}

\section{Result Data Processing ECM}

DP test of the residual value obtained from the

Table 1. Unit Root Test Results with the Augmented Dickey Test Fuller (ADF)

\begin{tabular}{cccccc}
\hline \multirow{2}{*}{ LEVEL } & \multicolumn{2}{c}{ 1ST DIFFERENT } & \multicolumn{2}{c}{ 2ND DIFFERENT } \\
\hline VARIABLES & PROB. & VARIABLES & PROB. & VARIABLES & PROB. \\
\hline PMDN & 0.9932 & $\mathrm{D}(\mathrm{X} 7)$ & 0.0000 & $\mathrm{D}(\mathrm{X} 7,2)$ & 0.0120 \\
EXPORT AGI & 0.1461 & $\mathrm{D}(\mathrm{X} 1)$ & 0.0000 & $\mathrm{D}(\mathrm{X} 1,2)$ & 0.0000 \\
EXPORT & 0.9666 & $\mathrm{D}(\mathrm{X} 2)$ & 0.9379 & $\mathrm{D}(\mathrm{X} 2,2)$ & 0.0009 \\
ZISWAF & 0.6555 & $\mathrm{D}(\mathrm{X} 8)$ & 0.0841 & $\mathrm{D}(\mathrm{X} 8,2)$ & 0.0002 \\
GDP & 0.9214 & $\mathrm{D}(\mathrm{Y})$ & 0.0000 & $\mathrm{D}(\mathrm{Y}, 2)$ & 0.0000 \\
\hline
\end{tabular}


estimated equation (4) is -1.078809 which is negative and has a statistical $F$ probability of 0.0035 which is $<0.05$. This shows that ECM's legal requirements have been fulfilled (Table 2).

The Export-Agi coefficient variable with a value of 44.875570 is the biggest most influential value in the long-term regression estimation. VariableDomestic Investment, Export-Agi and ZISWAF is positive, which means three in line with GDP, if the Export-Agi and ZISWAF grow, GDP will increase as well; whereas when the three decline or slow down, GDP will decline or slow down as well. Negative coefficient value of exports shows that exports have the opposite relationship with economic growth in GDP (Table 3).

Long-term economic growth equation model of ECM be:

PDBt $=8,030520$ PMDNt $+44,87557$ EKSPOR AGIt

$-8,951954$ EKSPORt + 132.7093ZISWAFt +

895104.3

The results of the regression model T-Test shortterm and long-term indicate that ZISWAF variables have a significant effect on economic growth variables at a 95 percent confidence level. The regression R-square value of the short-term model produces 26 percent of the effect of variable proportions of PMDN, Export-AGI, Export, and ZISWAF to GDP, which means that there have 74 per cent of other variables outside the model that affect GDP. Rated R-square of long term result in the proportion of 96 per cent of the effect of variable Domestic, Export-AGI, Export, and ZISWAF to GDP, only 4 percent are influenced by variables outside the model, meaning that the independent variables are tested to provide almost all the information needed to predict the dependent variable.

The ECM model short-term derivative economic growth equation is: $\mathrm{D}(\log (\mathrm{GDPt}))=\alpha 0+\alpha 1 \mathrm{Dt}+\alpha 5 \mathrm{D}(\log$ (ZISWAFmt1)) + ECT $(-1)$

$\mathrm{D}(\log (\mathrm{GDP} t))=0.023339+0.036501 \mathrm{D}(\log$ (ZISWAFmt-1)) - 1.81E-07ECT(-1)

The ECT coefficient of the above equation is

Table 2. Log regression results for the 2 nd Different with Augmented Dickey Fuller Test (ADF)

\begin{tabular}{lccl}
\hline VARIABLES & \multicolumn{2}{c}{ STASIONER 2nd Different } & \multirow{2}{*}{ Information } \\
\cline { 2 - 3 } & ADF & Prob & \\
\hline D(LOG(EKSPORT AGI) & 0.002265 & 0.9597 & Not Stationer \\
D(LOG(EKSPORT) & -0.000508 & 0.9884 & Not Stationer \\
D(LOG(PMDN) & 0.039820 & 0.3051 & Not Stationer \\
D(LOG(ZISWAF) & 0.036501 & 0.0366 & Stasioner \\
RES(-1) & $-1.81 \mathrm{E}-07$ & 0.0035 & Stasioner \\
\hline
\end{tabular}

Table 3. T-test results on the Regression model

\begin{tabular}{lccl}
\hline \multicolumn{1}{c}{ VARIABLES } & COEFFICIENT & Prob. (stat) & HYPOTHESIS TEST \\
\hline EXPORT-AGI & \multicolumn{2}{c}{ LONG TERM } & \\
EXPORT & 44.8756 & 0.0066 & Significant \\
PMDN & -8.9519 & 0.0000 & Significant \\
ZISWAF & 8.0305 & 0.0000 & Significant \\
& 1.3271 & 0.0000 & Significant \\
\hline D(log(EKSPOR AGI)) & 0.0023 & 0.9597 & Not Significant \\
D(log(EKSPOR) & -0.0005 & 0.9884 & Not Significant \\
D(log(PMDN) & 0.0398 & 0.3051 & Not Significant \\
D(log(ZISWAF) & 0.0365 & 0.0366 & Significant \\
\hline
\end{tabular}


-1.81E-07 meaning that there are increasing GDP will be adjusted within one (1) year with the residual speed of the balance value of -181 percent.

This research proveds that in the long and short term ziswaf has a significant influence on economic growth. In the long run, AGI-Export has the biggest positive effect compared to the positive effect of domestic investment and Ziswaf; As for long-term exports and export- AGI significantly affect economic growth, but otherwise has no effect on GDP.

Stages Analysis effect of domestic capital investment, international trade and ISF on sustainable economic growth in Indonesia Indonesia is a country undergoing transformation (Daryanto, 2009) characterized by farmers who own less than half a hectare of arable land and traditional harvests that produce little employment and income. Ziswaf's research illustrates the religiosity of a community with a large Muslim population in Indonesia having a high level of generosity and social care. If well maintained is a great potential to achieve higher GDP through ISF contribution, it means the future. The existence of a negative export to GDP can occur because the amount of exports is too small and there is a far greater influence due to world demands, trade policies that impose a country at the time or too many similar imported goods.

Even though his condition seems unfavorable, but adherents of Islam do not give up and continue to increase hard efforts because Allah subhanahu wa taa'ala has guaranteed every wealth. When farmers / producers have not been able to produce better quality, the potential for increased income will also increase by increasing value-added production, in addition to the community can increase consumption of domestic products that are also of higher quality and reduce consumption of imported products. With the increased ability of producers, trade can be increased by expanding markets, including addressing the needs of domestic interisland islands and also meeting export standards.
With the enactment of the Halal Product Guarantee Act (JPH), agricultural products, postharvest handling and supply of agricultural products to the food or pharmaceutical industry must meet halal standards to facilitate the halal industry output process, the halal value chain becomes important. The food industry can be developed step by step, conditioned by its production capacity and industrial capability. Provision of financing from Islamic banking can be done in every step of industrial development. By increasing the assets and capabilities of producers, trade can be increased by expanding markets, including entering international markets.

A country's exports and imports form the basis of foreign trade. A country must have at least one industry which produces products / goods more efficiently compared to other countries; resulting from the optimal use of resources. International trade is a representation of a significant part of the output of many countries. Even though the risk of international trade is higher than domestic trade, if it has been identified then efforts to control risk will be the effect of the next task. Risks that often arise are 1) Exporters who do not familiar with buyers, 2) Exporters do not know that importers are a good credit risk, 3) Exporters do not paid by importers, 4) Political stability that affects shipping goods abroad in certain parts in this world (Eun, Resnick \& Sabherwal, 2014).

Weakening global demand is the time to introcheck and evaluate the performance of existing commercial products and improve the quality and trading system to be more efficient, both related to selling prices and commodity volumes. A high exchange rate will benefit exports, but if demand is low it will not help improve the trade balance. When world demand is low, the domestic market will enjoy goods of better quality (export standards) and may reduce the tendency of imports of the same goods. This will improve the performance of the trade balance. On the process of collecting research data it is known that the potential of wakafs land is very large and is still not fully managed properly. This is supported by 
research evidence that domestic investment in the long term has a real influence on economic growth, but in the short term it has no real effect and ziswaf has a significant positive effect on GDP both in the short and long term.

Enjoying the grace of Allah subhanahu wa ta'alaa Almighty, so when weakening global demand is the right time to inspect and evaluate goods / products, examine and replace imported production materials by substituting equivalent local products, develop product innovations and better processing technologies, prepare trading systems to be more efficient both related to selling prices, commodity volumes and preparing agricultural goods / products that meet the World Trade Organization rules. And the most important thing is to increase production by increasing the area of production land and increasing the capacity of the processing industry and preparing the formal legal aspects of the contribution of waqf in the process.

Regarding fiscal policy, a high currency exchange rate will benefit exports, but if the volume of demand is low it will not help improve the trade balance. It is precisely in these conditions that raw-material imports become a trap because they are a burden on the negative trade balance, a negative contribution to GDP. When world demand is low, the domestic market will enjoy better quality goods (export standards) and can reduce the tendency of imports of the same goods, and when world demand rises this will improve the performance of the trade balance. Economic growth will change people's demand.

Barokah land-and-oceans Indonesia with a variety of plants and animal that become commodity income countries. During 2012-2018 the role of non-oil and gas exports averaged 86.48 percent per year. When viewed into commodities, non-oil and gas exports have always been dominated by exports of manufactured products from the period 2012 to 2018. The average contribution of manufacturing industry exports to non-oil and gas exports during the period 2012 to 2018 was 80.54 percent. The biggest agricultural commodity in 2018 is from annual crop commodities $(59.45$ percent), sorted from the largest value is coffee, aromatic- medicinal plants and spices, white pepper, tobacco, and other horticultural crops. Commodities of capture fisheries, aquaculture and livestock are swallow-nest, crab, seaweed and other algae, and crabs. Other agricultural commodities are rubber-gum and the like, sandalwood (BPS, 2019).

The manufacturing sector is the main sector of supporting the country's economy. Food industry commodities contribute 62.73 percent worth 26.27bn US\$ supported by palm oil (Unsolid fractions of refined palm oil, Crude palm oil-Palm kernel oil-Rbd, Solid fractions of refined palm oil, solid fractions of refined palm kernel oil, palm kernel olein-(refined, bleached \& deodorized), frozen shrimp, coconut oil (fractions of Refined coconut oil-Not chemically modified, crude oil of coconut/copra, crude oil of palm kernel), butterfat-cocoa oil, frozen fish, instant coffee and black tea, bread and cakes, oil-cake and other solid residues of palm nuts or kernels, cuttle fish and squid-frozen, hydrogenated \& Rbd palm kernel stearin or olein, frozen fillets of tunas, skipjack or stripe-bellied bonito, tilapias-frozen, cocoa paste,wholly/partly defatted, coconuts-desiccateddried, cashew nuts-shelled-fresh or dried, oth pasta-oth instant-noodles, pineapples-othwise prepared / preserved, oth sugar confectionerynot cont.cocoa-oth soft-cont gelatin (Kemenperin, 2017).

The second biggest value of export performance is the Chemical Commodity Industry and Chemical Goods, which includes industries that are changing organic materials and non- organic raw with chemical processes and product formation processes. Exports of chemical industry commodities and goods from chemicals on analysis. This refers to the 2015 KBLI concept. The industry share includes basic organic chemistry sourced from agricultural products (36.82 percent), Basic organic chemistry sourced from oil (12.45 percent), soaps and materialscleaners-home-purposes (10.84 percent), artificialresin/synthetic resins (8.44 percent), and-other 
raw materials (fertilizer, essential oils). The third largest value of export performance is rubber commodities, rubber goods and plastics. Indonesia's rubber production is ranked second in the world's largest rubber producer after Thailand, followed by Vietnam in the third position with the most extensive ownership of Indonesia's rubber land. Rubber is a commodity that is used in many products and equipment throughout the world. The export share consists of Crumb Rubber which is a raw material for several downstream rubber products such as tires, conveyor belts, vehicle spare parts, dock fenders, vulcanizers, and others, outer-and-inner-tires, and other goods from other rubber.

Competitiveness and performance of the state indicates the ability to sell and supply goods and services in the market is better than the ability of other countries in the same market. Factors of comparative advantage can be regarded as natural factors, while the competitive advantage factor is a factor that can be developed. RCTA indicator (Revealed Comparative Trade Advantage) is a commonly used index to see the development of export and import growth for the same product. There are 81 Indonesian agricultural commodities that have a positive RCTA value, which means they have competitiveness (comparative advantage) in the world and domestic markets (FAO, 2011).

Factors of comparative advantage can be considered as a factor, while its natural competitive advantage factor can be considered a factor that can be acquired or developed. The index commonly used to see the development of exports and also the development of imports for the same product is RCTA (Revealed Comparative Trade Advantage). The results of the competitiveness analysis with the RCTA indicator from FAO, 2011 show that based on the average value in 2009-2011, as many as 81 Indonesian agricultural commodities have a positive RCTA value, which means they have competitiveness (comparative advantage) in the world and domestic markets. The most competitive commodity is palm kernel oil (20.93) as presented in TableApendix. Revealed Trade Comparative
Advantage (RTCA) is an index used to measure the relative gains or losses of certain commodities in a country which is verified from its trading patterns, such as export market share (Table Appendix).

Policy makers face challenges when designing government initiatives aimed at encouraging the development of new green sectors, namely what green sectors will be promoted. In industrial policy this selection process often fails. The government needs to design a policy package to support sectors that have comparative advantages in agriculture, so industrial policy is likely to succeed. The natural and comparative advantages of the region in recent years have been clear to several developing countries such as the Technology and Information services in India and Mauritus, the salmon and wine industry in Chile, and the cut flower sector in Kenya (The International Institute for Sustainable Development, 2014).

\section{Stages Analysis Strengthening IBs with Partnership Financing and Sukuk}

The main driver of economic growth from an environmental standpoint and today is the expansion of global trade liberalization that does not harm the natural environment. Global trade finance volume reached US $\$ 23.4$ trillion, or onethird of global GDP. Studies of the impact of changes on the economic aspects of climate change by ADB (Asian Development Bank) showed in 2010, the influence on figures of 2.2 percent to 6.7 percent of GDP (Fauzi, 2010). International trade more difficult and risky than domestic trade export activity it showed demand for products of the country which means that the labor force is used to the technology. Therefore, the export-oriented company must have a good marketer, a competitive product, promotion, price and delivery capabilities as well as services rendered to the importer. As important as a competitive company in providing credit to the importer, the government exported great support to domestic exporters competitive in the form of loans that can be extended to importers (Eun, Resnick \& Sabherwal, 2014).

Financial greetings will solve problems on farm 
related to: fertilizers, insecticides, herbicides and storage facilities, etc. It can also function as a substitute for conventional agricultural finance in the state of Kano, Nigeria. Financial Salam is an Islamic financial product that is used by the Islamic banking industry to finance agricultural products and investments for economic growth and development. Financial greetings are good products for increasing agricultural output and overcoming the problem of agricultural products. This is the same, providing full advance payment and future delivery of agricultural produce at the agreed time.

Salam-finance are Islamic financial products used by the Islamic banking industry to finance agricultural products and investments for agricultural growth and development. Salamfinance Is a good products as agricultural financing to increase agricultural output and overcome the problem of agricultural products. This is the same, providing full payment in advance and delivery of agricultural products in the future at the agreed time. Salam- financing has been used for more than 1400 years in Medina (Ogonbado \& Ahmed, 2015). Implementation in Indonesia, where agricultural cultivation has shifted by reducing the use of chemical fertilizers and developing organic crops, greetings financing can be directed to provide quality seeds, crop maintenance, increase postharvest and increase the added value of farmers' products by developing agro-industry and also help access global marketing marketing.

The state of Kano, Nigeria established microfinance in 44 states' regional governments to tackle agriculture, trade, trade and industry issues. Later, Islamic banks introduced Salamfinance to replace the conventional mode of agricultural financing in the state. Rural farmers, traders, investors, branches of the Ja'is bank (Islamic bank) in the state of Kano will get many benefits. Expected to overcome the eradication of problems country such as food insecurity, poverty, unemployment, falling income of farmers and government. Microfinance can also be involved in parallel Parallel-Salam contracts.
Salam financing has the potential to reduce poverty, job opportunities, increase marketing activities, provide education and training. The availability of agricultural output in the state leads to the socio-economic stability of poor farmers and the country's economic growth.

On muslim community, an religiously acceptable banking services must be banking and fnancial system based Islamic principles. To run an agricultural project there is the principle of almuzara'a, al-musaqa and mugharasah need to understand two main ideas; leasing and profit sharing/partnership between property and work. In contrast to al-mudharabah, which is more suitable for trade contracts and industrial or commercial operations. So the understanding of al-muzara'a, al-musaqa and al-mugharasah can be defined in principle as a contract based on the division of products or results rather than profit sharing. Therefore, al-muzara' $a$ and al-musaqa can be identified as 'agricultural products and yields sharing' (aPLS), as opposed to al-mudharabah and al-musharaka known as 'Profit and loss sharing' (PLS). Land together with labor can be considered a form of capita land therefore has similarities with mudaraba and musharaka contracts. Therefore, it can be said that these principles are 'Agricultural Production and Yields Sharing (aPLS)' because land will naturally produce output or products. Therefore, Muzara'a and Musaqa can be said as a contract based on yields sharing and not profit sharing (Shafiai, 2012).

Further explained that Finance and Participatory (PF) those model has haved High Level of Risk. The risks associated with PF are one of the main challenges in implementing this financing model. Islamic Bankings (IBs) have the following high levels of inherent risk when involved in PF:

I) Lack of Ibs technical expertise due to the absence of appropriate monitoring mechanisms: In the absence of appropriate mechanisms for project and company evaluations, banks cannot measure project performance and value at various stages the life cycle of their business; 
ii) A high level of risk weight that is set: Capital adequacy standards do not really accommodate Musharakah and Mudarabah-based products. A high risk weight age has been established for these products, which is $400 \%$ as stated in IFSB Standard No. 15, whereas in BASEL III.2 it is $1000 \%$;

iii) Risk of sharia non-compliance: The risk of sharia non-compliance can also be a major concern in Musharakah and Mudarabah-based products. Because the project will usually be a long-term project and has a complex / hybrid structure, the bank may not be able to continue to monitor the project to ensure that it complies with sharia rules.

Today the use of participatory modes such as Mudaraba and Musharaka been absent, especially in the asset side of bank balance sheets. When some IBs execute Musharakah financings, it lacks true risk sharing as the return its based on conventional pricing benchmark. These practices have attracted criticism on the current model of Ibs. Ibs contrary to conventional banks, are supposed to achieve greater socioeconomic objectives such as social justice, economic growth, efficiency and stability, and these objectives can be better served through the use of these participatory modes of financing. It is also viewed that these modes have the potential to better serve the stakeholders through equitable and broad-based distribution of risk and rewards among the entrepreneur, banker and depositors and promote stability of the financial and economic system. Currently, the development of global sukuk very quickly, and become an investment option businessman. Based on the sukuk issuer may be issued by corporations and governments.

In short, the mechanisms, waqf and agricultural idle land is a new innovation in waqf development in the contemporary era. The scheme aPLS (agricultural production and loss sharing) that proposed cannot stand alone in the traditional fiqh to be implemented now. Therefore, the combinations of aPLS contract with ujrah principle are really needed. Be important to ensure the flexibility of the contract that can offer a fully comprehensive scheme of Islamic agricultural financing. Nevertheless, the applications of these mechanisms are not without controversies. It's important to mention that waqf utilization in the waqf system received a lot of debates among the fiqh scholars and modern scholars.

Management of waqf land for agriculture can apply other principles such as al-ijarah muntahiya bi-tamlik, al-murabahah and bay al-salam. At present Islamic banking institutions tend to apply two-tier al-mudarabah, not one-sided almudarabah in classical theory, where banks accumulate deposits from their customers and invest in third parties. Islamic financial experts are more appropriate in applying the principles of al-muzara'ah and al-musaqah, which are more relevant and increase th e practicality of transactions in Islamic banking / financial institutions. Required steps must be determined from many parties, including academics and practitioners to improve this product (Shafiai \& Moi, 2015).

Othe $\mathrm{r}$ principles such as al-ijarah muntahiya bi-tamlik, al-murabaha and bay al-salam can also be included. IBs institutions currently tend to apply two-tier al-mudarabah, not one- sided almudarabah in classical theory, where banks accumulate deposits from their customers and invest them in third parties. Islamic finances (IFs) experts more precisely implement the principles of al-muzara'ah and al-musaqah. This is more relevant for improving the practicality of transactions in Islamic banking and financial institutions. The necessary steps must be determined from many parties, including academics and practitioners to improve this product (Shafiai \& Moi, 2015).

Food processing industry development should prioritize high usage of imported raw materials and weaken the performance of net trade balance of Indonesia. Financing agricultural (A-financing) by IBs /IFs institutions in the long term, it needs to be directed to the industrial development of 
import substitution of raw materials, the development of local production into innovative product export standards, developing innovative industrial equipment is good and cheap. In terms of the availability of clean water is also needed to increase agricultural crop production and quality of agricultural products processing industry generated. Related to ISF, waqf-wells are an alternative for the people of Indonesia, can be mixed with government funding through the construction of irrigation infrastructure for areas in need. This problem can be solved by implementing Musaqa or Istishna contract.

PT Perkebunan Nusantara (c.q. PTPN) is the one of a state agency related to tea and palm plantation products which are spread in several regions in Indonesia. It's time for the state agency to be able to contribute in state revenue. The extent of land has not been maximally produced, if assisted with Islamic financial financing, it is possible to improve its performance and contribute to an increase in state income from the agricultural sector. Likewise, well-managed forest land will certainly get the balance of the ecosystem and improve the welfare of the surrounding poor communities. In general, plantation company transaction activities are divided into several stages, including: nursery stage, land preparation stage, planting and transplanting stages to the land area, treatment and fertilization Stage, harvest and harvest-handling stage, harvest product processing stage, and marketing endproduct. One way to increase business capital is to issue agricultural sukuk with a special agricultural contract.

Explanation cooperation agreement based on alMuzaraah, al-Musaqah and al-Mugharasah are: 1) Al-Muzara'ah is a contract of agricultural business cooperation between the land owner and the manager (cultivators), where the seeds of the plant come from the land owner and agricultural products are shared between the owner and the cultivator according to the agreed ratio. 2) $\mathrm{Al}$ Musaqah is a contract of cooperation between the land owner and the cultivator in the framework of maintaining plants to grow and bear fruit well, the results of which are shared between the owner and the cultivator according to the agreed ratio 3 ) Mugharasah is a contract of cooperation between the land owner and the cultivator in the context of securing a hard tree where the harvest is the tree (not the fruit), the results are shared between the land owner and the cultivator according to the agreed ratio.

The multiple impact of improved trade performance is that welfare at the farm level (upstream) and downstream will also increase. A good post harvest must be introduced to farmers so that they will always get a high bargaining position. The IBs or Islamic financing scheme through the agreements above made it possible, Insyaa Allah. Proposed sharia bank partnership scheme in Figure 3.

\section{CONCLUTION AND POLICY ADVICER}

\section{Conclusion}

1. International trade Exports-AGI and Export, PMDN investment and IS F - Ziswaf was affecting national growth of GDP with significant. In the long term, the economic growth of GDP is affected simultaneously by all independent variables, and is significantly affected positively by international trade Agi Exports, PMDN investments and ZISWAF sosio economy fund; and significantly influenced negatively by the international trade of Export at the R-square level of 0.98. In the short term, economic growth of GDP was significantly influenced by ZISWAF sosio economy fund on R-square 0.26 .

2. Partnership Financing and Sukuk are very potential to be developed for large-scale agricultural projects, both for the cultivation of annual crops, plantations, forestry and other potentially competitive crops with financing agreements like Salam, Muzara'ah, and Mugharasah. Irrigation infrastructure for areas prone to lack of water with Musaqa or Istishna financing.

\section{Policy Maker}

1. The government through the Ministry of Religion and the Endowment Board more encourages the development of unemployed 


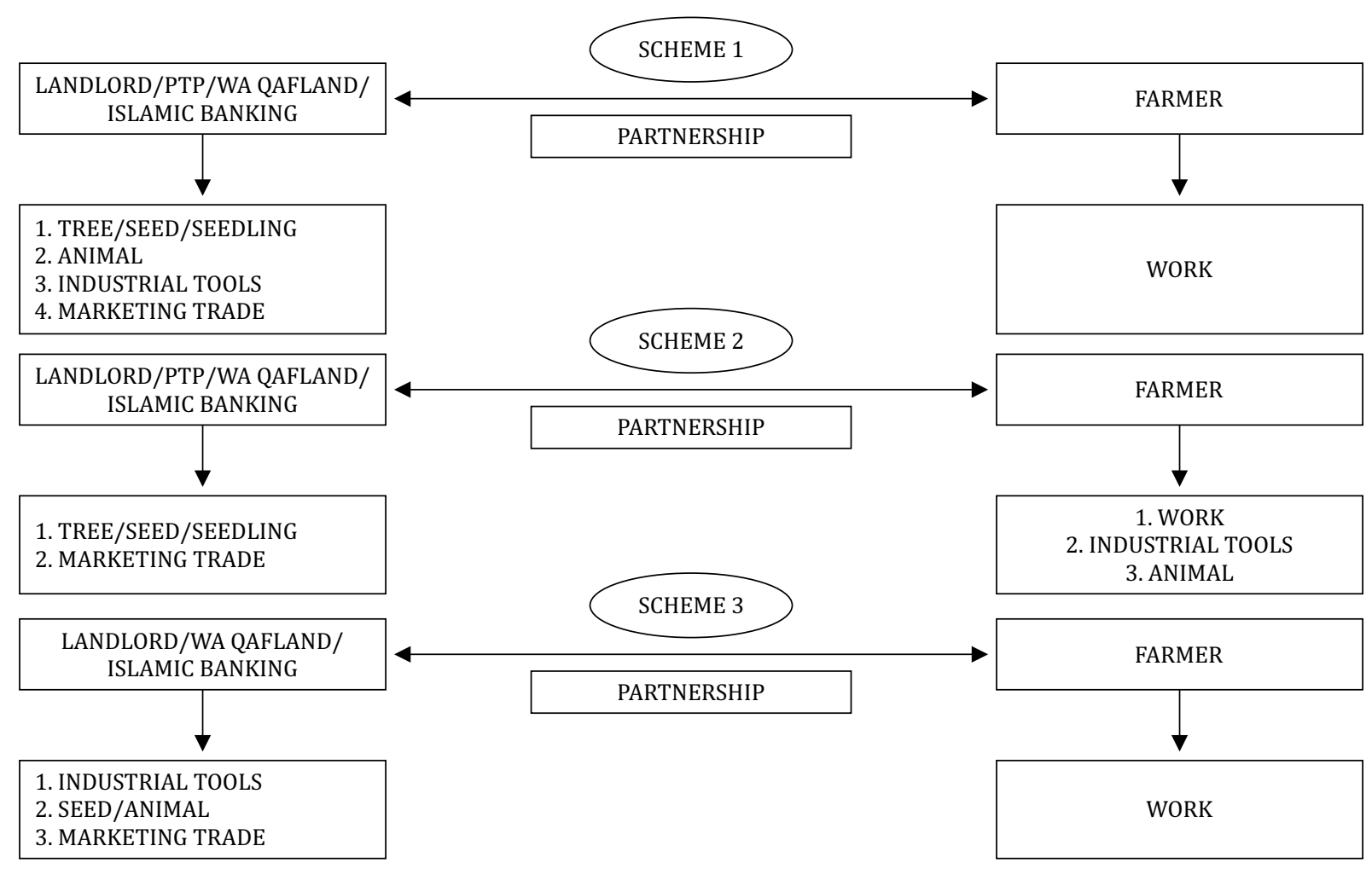

Figure 3. Financing Partnership Scheme

land through the ownership of manufacturing industries that produce raw materials that meet the needs of domestic industries and then export-oriented to reduce domestic dependence on imported raw materials, through coordination between three ministries namely agriculture, trade and industry.

2. The government and IB must encourage the part of Islamic financial institutions namely the concept of 'smart microfinance', which provides a variety of products to accompany vulnerable people in the SDGs, through economic empowerment, but will also ensure that these communities are adequately equipped and empowered by strengthening capacity technical and managerial, building partnerships, accessing markets, identifying and managing climate risks in their activities, etc.
3. The intermediary function of the IB must provide financing products based on ethics and contracts permitted by the central bank, the fatwa of the local ulama and the state financial authority board. Issuance of investment sukuk can be informed by the IB or the government through the ministry of finance and related bodies / waqf who are unemployed landowners.

4. Ecosystems that drive liquidity to the real sector must be maintained. The Central Bank together with the finance ministry and the Indonesian central bank must be able to maintain macroeconomic stability through government fiscal policies and monetary and exchange rate stability, low interest rates, and inflation that are lower than the target, so that the business climate continues to perform well. 


\section{REFEREN CES}

AAOIFI. (2004) Sharia'a Standars. 2004-5. Accounting \& Auditing Organization for Islamic Finance Institutions. ISBN 99901-23-06-3 P.O.Box 1175. Manama, Bahrain. Email: aaoifi@batelko.com.bh Website: www.aaofi.com

Abdul-Rahman, Y. (2010). The Art of Islamic Banking and Finance - Tools and Techniques for Communitybased Banking. John Wiley \& Sons, Inc. Hoboken, New Jersey.

Anderson, K. (2010). Review. Globalization's effects on world agricultural trade, 1960 - 2050. School of Economics, University of Adelaide, Australia. Philosophycal Transaction of Royal Socciety. B (2010) 365, 3007-3021. doi:10.1098/rstb.2010.0131

Agustianto. (2008). Wakaf Produktif Untuk Kesejahteraan Umat. Niriah, Jakarta. 7

Al- Quranul Karim. (2011). Terjemah Kata Per Kata. CV Insan Kamil. Jl. Babakan Sari I No.71 Kiaracondong, Bandung 40283.

Ahmad, M. (2015). Role of Waqf in Sustainable Economic Development and Poverty Alleviation: Bangladesh Perspective. Journal of Law, Policy and Globalization. ISSN 22243240 (Paper) ISSN 2224-3259 (Online) Vol.42, 2015

Ashraf, B. N. (2017). Do Trade and Financial Openness Matter for Financial Development? Bank-level Evidence From Emerging Market Economies. Research in International Business and Finance. Volume 44, April 2018, Pages 434-458

Azis, R. M. (2009). Kaffah Thingking on Simlammim Method Through Digital Root. Proceeding. ISOIT International Seminar on Ismalic Thought, UKM, Bangi, Malaysia.

Badan Wakaf Indonesia. (2016). Himpunan Peraturan Perundang-Undnagan tentnag Wakaf. 260 halaman.

Bank Indonesia. (2007). Peningkatan Peran Bank Indonesia dalam Mendorong Pertumbuhan Ekonomi Melalui Pemetaan Sektor Ekonomi: Laporan Pemetaan Ekonomi Sektor Pertanian. Biro Neraca Pembayaran, Direktorat Statistik Ekonomi dan Moneter. Jakarta.

Cervantes, G. D., and Dewbre, J. (2010) “Economic Importance of Agriculture for Poverty Reduction”, OECD Food, Agriculture and Fisheries Working Papers, No. 23, OECD Publishing. doi: 10.1787/5kmmv 9s20944-en

Dermoredjo et al. 2015. Pemetaan Daya Saing Pertanian Indonesia. Laporan Akhir TA 2015. Pusat Sosial Ekonomi dan Kebijakan Pertanian. Badan Penelitian dan Pengembangan Pertanian. Kementerian Pertanian. Jakarta.

Eun, C. S., Resnick, B. G. And Sabherwal, S. (2013). International Finance, $6^{\text {th }}$ Edition. McGrawHill Education (Asia). Terjemahan Penerbit Salemba Empat.

http://www.fao.org/fsnforum/zh/topics/resources/household-food-security?page=2

https://globalwakaf.com

https://kemenperin.go.id/statistik/peran.php?ekspor=1

Fauzi, A. (2010).The Economics of Climate Change in South East Asia: A Regional Review. Review ADB's Review.

Gujarati, D.N. (2004). Basic Econometrics, (4th ed.). The McGraw-Hill Co.

Hadad, S. M. (2016). Pidato Ketua Umum Ikatan Sarjana Ekonomi Indonesia. Inovasi Rantai Nilai Sektor Agro dalam Mendukung Implementasi Financial Inclusion Untuk Petani. KADIN, ISEI, PISAgro - Balai Kartini, Jakarta, 23 Mei 2016.

https://www.bps.go.id/publication/2019/08/02/8790fedf90b47c11b009a5ca/analisis- komoditasekspor--2012-2018--sektor-pertanian--industri--dan-pertambangan.html

https://mui-lplhsda.org/pandangan-islam-terhadap-ketahanan-air-pangan-dan-energi-bangsa/

International Institute for Sustainable Development. ( 2014). Trade and Green Economy. A Handbook. Third Edition. The United Nations Environment Programme Division of Technology, Industry and Economics Economics and Trade Branch and The International Institute for Sustainable 
Development. Published by the International Institute for Sustainable Development. Printed in Geneva, Switzerland.

Josling, T., Anderson, K., Schmitz, A., \& Tangermann, S. (2010). Understanding International Trade in Agricultural Products. Amer Journal. Agr. Econ. 92(2): 424- 446; doi: 10.1093/ajae/aaq011. Received December 2009; accepted January 2010; April 2010

Miller, H. M. (1998) Financial Markets and Economic Growth, Journal of Applied Corporate Finance September 1998, Vol. 11 No. 3 (Fall 1998), pages 8-14

Mulyawan, D. (2017). Kontribusi Islamic Social Finance Dalam Percepatan Pertumbuhan Ekonomi Nasional. Materi Seminar Nasional: Islamic Capital Market and Economic Development. 1 Maret 2018. Kementrian Keuangan-Universitas Gunadarma, Depok.

Myers, T. A., and Hassazadeh, E. ( 2013). The Interconection Between Islamic Finance and Sustainable Financing. IISD Report. Publised by The International Institute for Sustainable Development. 161 Portage Avenue East, $6^{\text {th }}$ Floor, Winnipeg, Manitoba, Canada R3B 0Y4. www.iisd.org

Mohammed, A. I., Ogunbado, A. F., \& Bashir, A. (2016). The Viability of Salam Finance in the Growth of Agricultural Production in Kano State, Nigeria. Asian Journal of Multidisciplinary Studies, 4(12), 87-92.

Naufal, A. (2010). Peranan Sektor Pertanian dalam Pertumbuhan Ekonomi dan Mengurangi Ketimpangan Pendapatan di Pemerintah Aceh.

OJK. (2017). Roadmap Map Ekonomi Berkelanjutan 2015-2018

Putra, A. (2014). Implementasi Kebijakan Green Growth di Korea Selatan. Jom Fisip Volume I No.2 Oktober 2014. Riau-Pekanbaru.

Samad, M. (2016). Fiqih Lingkungan, Solusi Pemanasan Global dan Masalah Lingkungan dari Sisi Agama Islam. Lembaga Adat Melayu Riau, Pekanbaru.

Setyaningsih, P., Aziz, R., \& Hadiyati, P. (2019). Analysis of Ziswaf, Production Index and Sharia Stock Index on Economic Growth. Jurnal Pasar Modal Dan Bisnis, 1 (2), 221-242. https://doi.org/10.37194/jpmb.v1i2.32

Shafiai, M. H. M., Moi, M. R., \& Ahmad, R. (2015). The Potential of Waqf in Activating Idle Agricultural Land. Jurnal Pengurusan 44(2015) $141-147$

Shafiai, M. H., \& Moi, M. R. (2015). Fitting Islamic financial contracts in developing agricultural land. Global Journal Al-Thaqafah, 5(1), 43-49. https://doi.org/10.7187/GJAT772015.05.01

Sutawijaya, A. (2010). Pengaruh Ekspor Dan Investasi Terhadap Pertumbuhan Ekonomi Indonesia Tahun 1980-2006. Jurnal Organisasi Dan Manajemen, 6(1),14-27.

Usher, E. and Ndiaye, D. (2020). 2020: The Year Sustainable Islamic Finance Scales? https://www.responsible-investor.com/articles Mar 2nd, 2020 


\section{APENDIX}

Table 1. Positive RCTA Value of indonesia Agricultural commodities (2000 - 2011)

\begin{tabular}{|c|c|c|c|c|c|}
\hline Komoditas & Rataan 2000-02 & Rataan 2003-05 & Rataan 2006-08 & Rataan 2009-11 & Rataan 2009-11 \\
\hline Oil, palm kernel & 31,4525 & 27,23601 & 23,46205 & 20,92518 & 1 \\
\hline Oil, palm & 20,86654 & 20,30643 & 17,1123 & 15,82169 & 2 \\
\hline Cake, palm kernel & 19,05038 & 19,41593 & 18,1185 & 15,25921 & 3 \\
\hline Rubber natural dry & 21,65471 & 18,70652 & 15,8569 & 12,45144 & 4 \\
\hline Oil, coconut (copra) & 19,07756 & 13,65663 & 12,99636 & 9,54687 & 5 \\
\hline Cake, copra & 25,23266 & 21,11713 & 15,22671 & 9,47079 & 6 \\
\hline Coconuts & 17,84315 & 13,19484 & 13,092 & 9,04703 & 7 \\
\hline Cinnamon (canella) & 11,33397 & 9,85252 & 7,57106 & 5,58154 & 8 \\
\hline Copra & 12,77681 & 13,97122 & 7,07683 & 5,55218 & 9 \\
\hline Nutmeg, mace and cardamoms & 11,65576 & 12,14205 & 8,55835 & 5,45392 & 10 \\
\hline Fatty acids & 5,23178 & 5,27797 & 5,1156 & 5,45044 & 11 \\
\hline Waxes vegetable & $-1,26124$ & $-0,98307$ & 5,04896 & 5,07304 & 12 \\
\hline Pepper (piper spp.) & 14,99865 & 8,5454 & 5,67585 & 5,0154 & 13 \\
\hline Coconuts, desiccated & 11,49705 & 6,88426 & 5,46531 & 4,60719 & 14 \\
\hline Pineapples canned & 9,96799 & 7,34397 & 4,81333 & 4,487 & 15 \\
\hline Cocoa, beans & 8,29141 & 4,83646 & 5,16972 & 3,566 & 16 \\
\hline Flour, roots and tubers nes & 1,61138 & $-3,56537$ & $-7,73311$ & 3,36036 & 17 \\
\hline Margarine, short & 7,10282 & 4,3329 & 5,07041 & 3,26412 & 18 \\
\hline Cashew nuts, with shell & 8,14884 & 10,10293 & 6,44339 & 3,2386 & 19 \\
\hline Bran, wheat & 10,05308 & 7,32542 & 4,3819 & 3,16012 & 20 \\
\hline Meat, nes & 10,12441 & 5,24315 & 3,6942 & 3,00064 & 21 \\
\hline Cocoa, butter & 4,42295 & 3,63192 & 3,14121 & 2,37186 & 22 \\
\hline Fat, nes, prepared & $-0,12689$ & $-0,01461$ & $-0,1517$ & 2,23569 & 23 \\
\hline Juice, pineapple, concentrated & 44,87243 & 6,88593 & 2,70575 & 1,79031 & 24 \\
\hline Cotton waste & 2,11599 & 2,2774 & 2,12669 & 1,69175 & 25 \\
\hline Coffee, green & 2,92568 & 2,83187 & 2,11373 & 1,58973 & 26 \\
\hline Sweet potatoes & 4,67224 & 4,38048 & 2,78269 & 1,37991 & 27 \\
\hline Vanilla & 7,39582 & 2,98559 & 2,16323 & 1,34983 & 28 \\
\hline Molasses & $-1,37628$ & $-0,06846$ & 2,14755 & 1,3049 & 29 \\
\hline Wafers & 0 & 0 & 0 & 0,87541 & 30 \\
\hline Cigarettes & 1,00932 & 0,7379 & 0,70618 & 0,83296 & 31 \\
\hline Tea & 2,8229 & 1,96928 & 1,18219 & 0,74595 & 32 \\
\hline Cassava dried & 2,72764 & 1,87125 & 1,28502 & 0,66626 & 33 \\
\hline Cigars, cheroots & 0,32488 & 0,42133 & 0,51188 & 0,60014 & 34 \\
\hline Oilseeds nes & 1,13598 & 1,72019 & 0,44729 & 0,59922 & 35 \\
\hline Cocoa, powder \& cake & 2,3039 & 1,66906 & 0,80425 & 0,5559 & 36 \\
\hline Coffee, extracts & 0,63567 & $-0,16313$ & $-0,61$ & 0,49394 & 37 \\
\hline Wool, hair waste & 0,05653 & 0,0203 & $-0,05001$ & 0,42091 & 38 \\
\hline Mushrooms, canned & 3,22989 & 1,48627 & 0,82774 & 0,35654 & 39 \\
\hline Cocoa, paste & 0,97359 & 0,19872 & 0,10768 & 0,34065 & 40 \\
\hline Spices, nes & 0,25341 & 0,28842 & 0,23409 & 0,27996 & 41 \\
\hline Oil, olive residues & 4,39275 & 1,98817 & 0,17221 & 0,25462 & 42 \\
\hline Cabbages and other brassicas & 1,23016 & 0,99137 & 0,49828 & 0,24717 & 43 \\
\hline Oil, essential nes & 2,24311 & 1,0865 & 0,96502 & 0,18778 & 44 \\
\hline
\end{tabular}


Purbawati Setyaningsih, Acep R. Jayaprawira / Strengthening Agricultural Investment Through Sustainable Islamic Banking / 82 - 103

\begin{tabular}{|c|c|c|c|c|c|}
\hline Cashew nuts, shelled & 0,55206 & 0,46 & 0,50835 & 0,17276 & 45 \\
\hline Pastry & 0,29305 & 0,29 & 0,1433 & 0,15721 & 46 \\
\hline Sugar confectionery & 0,72504 & 0,18148 & 0,09308 & 0,13979 & 47 \\
\hline Cereals, breakfast & $-0,23583$ & $-0,21089$ & $-0,21823$ & 0,12217 & 48 \\
\hline Oil, vegetable origin nes & 0,25725 & $-0,18466$ & 0,04761 & 0,11996 & 49 \\
\hline Bran, rice & $-3,42969$ & $-0,43605$ & 0,03445 & 0,08739 & 50 \\
\hline Lard & 0,22342 & 0,03941 & 0,05118 & 0,08078 & 51 \\
\hline Cotton linter & $-0,00241$ & $-0,00382$ & 0,14366 & 0,07898 & 52 \\
\hline Bread & 0,09715 & 0,0497 & $-0,07847$ & 0,06953 & 53 \\
\hline Cake, cottonseed & 0,52641 & 0,32708 & 0,74274 & 0,06454 & 54 \\
\hline Flour, pulses & $-0,32534$ & $-1,94676$ & $-5,21936$ & 0,06432 & 55 \\
\hline Waters,ice etc & 0,21907 & 0,09188 & $-0,01589$ & 0,06273 & 56 \\
\hline Eggplants (aubergines) & 0,8579 & 0,5777 & 0,04485 & 0,05955 & 57 \\
\hline
\end{tabular}

Source: FAO (2011), processed 